\title{
Pengetahuan, sikap dan persepsi masyarakat tentang kanak-kanak Autism Spectrum Disorder (ASD)
}

\section{Knowledge, Attitude and Social Perception of Autism Spectrum Disorder (ASD) Children}

\author{
Zainoriza Zainun ${ }^{1}$, Abdul Halim Masnan ${ }^{2}$, Ahmad Zulfadli Ahmad Bakri ${ }^{3}$,Asiah @ \\ Nursyahira Jupari@ Jupry ${ }^{4}$, Siti Aishah Aspani ${ }^{5}$, Nurul Aini Hassan ${ }^{6}$, \& Zalizah Zawawi ${ }^{7}$ \\ Fakulti Pembangunan Manusia, Universiti Pendidikan Sultan Idris Tanjong Malim, Perak, \\ Malaysia ${ }^{1,2,3,4,5,6,7}$
}

zzainoriza@yahoo.com¹, abdul.halim@fpm.upsi.edu.my²,joijenoz@gmail.com³ asyira2019@gmail.com ${ }^{4}$, aishahaspani@gmail.com ${ }^{5}$, ainne_smart88@yahoo.com ${ }^{6}$, zalizahmaya@yahoo.com ${ }^{7}$

DOI: https://doi.org/10.37134/saecj.vol8.no1.3.2019

Received: 16 March 2019; Accepted: 23 May 2019; Published: 11 June 2019

\begin{abstract}
ABSTRAK
Kajian ini bertujuan mengenal pasti pengetahuan, sikap dan persepsi masyarakat terhadap kanak-kanak Autism Spectrum Disorder (ASD). Reka bentuk kajian ini adalah kaedah tinjauan dengan menggunakan soal selidik sebagai instrumen untuk mengumpul data kajian. Kajian ini melibatkan seramai 100 orang responden yang terdiri daripada guru, ibu bapa dan penjaga. Data bagi kajian ini telah dianalisis secara deskriptif dan inferensi. Dapatan kajian menunjukkan tahap pengetahuan, sikap dan persepsi masyarakat tentang kanak-kanak ASD adalah tinggi. Kajian juga menunjukkan tidak terdapat perbezaan pengetahuan, sikap, dan persepsi masyarakat tentang kanakkanak ASD mengikut jantina. Pengkaji juga mendapati pengetahuan dan persepsi masyarakat tentang kanakkanak ASD adalah berbeza mengikut tahap pendidikan, manakala sikap masyarakat tentang kanak-kanak ASD adalah tidak berbeza mengikut tahap pendidikan. Selain itu, dapatan menunjukkan terdapat hubungan kolerasi positif yang sederhana antara pengetahuan dengan sikap dan persepsi masyarakat tentang kanak-kanak ASD. Dapatan kajian ini diharapkan dapat menjadi panduan dalam memberikan input kepada para pengkaji dan pihak berkenaan bagi memastikan kanak-kanak ASD ini diterima oleh masyarakat dengan baik.
\end{abstract}

Kata kunci: kanak-kanak, Autism Spectrum Disorder (ASD), pengetahuan, sikap dan persepsi masyarakat

\begin{abstract}
The purpose of this study was to examine the knowledge, attitudes and social perceptions of Autism Spectrum Disorder (ASD) children. The design of this study is a survey method by using a questionnaire as an instrument to collect research data. A total of 100 respondents consisted of teachers, parents and guardians. The data for this study were analysed by descriptive and inference analysis. The findings show that the level of knowledge, attitudes and social perceptions of ASD children is high. The study also showed that there was no difference in knowledge, attitudes, and social perceptions about ASD children by gender. The researchers also found that knowledge and social perceptions about ASD children differed by education level, while social attitudes toward ASD children did not differ by education level. In addition, findings indicate that there is a moderate positive correlation between knowledge and attitudes and social perceptions of ASD children. The findings of this study are expected to serve as a guide in providing input to future researchers and stakeholders to ensure ASD children are accepted by society.
\end{abstract}

Keywords: children, Autism Spectrum Disorder (ASD), knowledge, attitude and social perception 


\section{PENGENALAN}

Setiap kanak-kanak yang dilahirkan ke dunia ini mempunyai kelebihan dan keistimewaan yang tersendiri. Walau bagaimanapun, terdapat kanak-kanak dilahirkan dengan ketidakupayaan dalam beberapa aspek. Antara kategori ketidakupayaan tersebut ialah kanak-kanak Autism Spectrum Disorder (ASD). Autisme merupakan ketidakupayaan perkembangan yang secara signifikannya mempengaruhi komunikasi lisan dan bukan lisan, dan interaksi sosial. Ketidakupayaan yang dimiliki oleh kanak-kanak tersebut bukan penghalang untuk mereka menikmati kehidupan dan mengalami keseronokan berada dalam alam kanak-kanak seperti kanak-kanak normal yang lain.

Pusat Pengawalan Penyakit (CDC) di Amerika Syarikat mentakrifkan bahawasanya satu daripada 68 bayi yang baru lahir menghidapi masalah ASD dan tingkah laku berkaitan. Manakala, The National Autism Society of Malaysia (NASOM) menganggarkan terdapat lebih kurang 9,000 kanakkanak di Malaysia dilahirkan menghidapi ASD setiap tahun. Kewujudan kanak-kanak ASD dalam kelompok masyarakat merupakan sesuatu yang perlu diraikan, bukan sesuatu untuk disisihkan.

Penerimaan masyarakat dan persepsi yang positif yang diberikan oleh masyarakat mampu menjadi nilai tambah kepada perkembangan positif kanak-kanak ASD. Soltanifar et al. (2015) menyatakan jika masyarakat memberikan stigma yang positif, ianya dapat menjadi satu sokongan yang positif kepada ibu bapa kanak-kanak ASD. Kesan daripada sokongan positif yang diterima oleh masyarakat pasti akan mendorong ibu bapa untuk membesarkan anak-anak ASD mereka dengan baik tanpa merasakan tekanan yang hebat dan juga rasa rendah diri yang menebal apabila berhadapan dengan masyarakat.

Walau bagaimanapun, bukan semua masyarakat memainkan peranan yang baik dalam memastikan perkembangan positif kanak-kanak ASD. Antara yang sering masyarakat tunjukkan ialah menyisihkan kanak-kanak tersebut selain daripada memberikan persepsi yang negatif. Khairul Azhar (2018) menyatakan masih terdapat lagi salah tanggapan terhadap kanakkanak ASD daripada keluarga terdekat dan masyarakat di sekeliling kanak-kanak tersebut. Tanggapan biasa terhadap kanak-kanak ASD ialah seorang cacat mental, tidak boleh belajar atau diajar, berisiko menjadi ganas dan tidak terkawal, berbahaya kepada orang lain, mengancam keharmonian ibu bapa dan keluarga serta masyarakat setempat. Salah tanggapan ini mampu menjadi penyebab yang membantutkan perkembangan kanak-kanak autisme ini.

Mohd Suhaimi dan Nur Natasha Amelia (2018) menyatakan masyarakat telah melabelkan ASD ini sebagai satu pandangan yang hina secara lisan atau bukan lisan. Keluarga yang mempunyai anakanak ASD ini sering kali menghadapi kesukaran dan mempunyai stigmatasi yang tinggi dalam kalangan masyarakat. Stigma ini adalah merupakan faktor utama kepada kejatuhan motivasi diri dalam kalangan ibu bapa yang mempunyai anak bermasalah ASD. Siti Marziah dan Nor Shahirah (2018) pula menyatakan layanan masyarakat terhadap ibu bapa bagi kanak kanak ASD sering bersifat memerli dan menyisihkan yang boleh menyebabkan tekanan dalam diri ibu bapa tersebut. Ini menunjukkan stigma dan pandangan yang telah diberikan oleh masyarakat telah menambahkan tekanan dan bebanan ibu bapa bagi kanak-kanak ASD.

Faktor yang menyumbang kepada sikap dan persepsi masyarakat terhadap kanak-kanak ASD yang bersifat negatif adalah disebabkan oleh kekurangan pengetahuan dan kefahaman masyarakat terhadap keperluan dan masalah kanak-kanak ASD itu sendiri. Menurut Suhaily dan Siti Syuhada (2017), kurangnya ilmu pengetahuan mengenai sindrom ASD menyebabkan persepsi masyarakat yang negatif mengenai kanak-kanak ASD yang seterusnya memberikan kesan negatif terhadap ibu bapa yang mempunyai anak ASD.

Meiriawan, Abdul Salim, dan Furqan (2017) menyatakan walaupun masyarakat sering mendengar tentang kewujudan kanak-kanak ASD, tetapi mereka tidak benar-benar memahami spektrum autisme secara terperinci. Kajian Suhaily dan Siti Syuhada (2017) mendapati ciri-ciri kanak- 
kanak ASD sering kali disalah anggap menyerupai ciri-ciri kanak-kanak hiperaktif. Kesedaran masyarakat mengenai ASD di Malaysia ini masih lagi berada di bawah tahap rendah, dan ianya tidak hanya terhad kepada masyarakat sahaja, malah guru arus perdana turut serta tidak arif mengenai ciriciri kanak-kanak ASD.

Hasnah, Mohd. Hanafi, Mohd. Mokhtar, dan Norani (2010) menyatakan guru pendidikan khas lebih cekap mengenal pasti ciri-ciri ASD ,akan tetapi mempunyai kekurangan input dari segi latihan dan pengetahuan yang diperolehi semasa belajar di universiti ataupun di institut perguruan (IPG). Hal ini disokong oleh Majin, Hashmi, dan Sombuling (2017) yang mendapati kurangnya pengetahuan tentang ASD dalam kalangan guru yang secara tidak langsung memberi kesan yang besar terhadap persepsi mereka terhadap kanak-kanak ASD di Malaysia.

Walaupun masyarakat kini kerap mendengar tentang autisme, namun masih ramai yang tidak memahami ciri-ciri kanak-kanak ASD yang sebenar. Justeru, kesedaran masyarakat dan kecekapan ibu bapa dan guru dalam menangani sindrom ASD ini perlu dititikberatkan daripada pelbagai sudut secara terperinci agar kewujudan kanak-kanak ASD ini lebih terbela seperti kanak-kanak yang lain. Keseluruhannya, sikap, pengetahuan dan persepsi masyarakat terhadap kanak-kanak ASD merupakan elemen yang dapat menyumbang kepada kekuatan dan ketahanan emosi ibu bapa kanak-kanak ASD serta perkembangan positif kanak-kanak tersebut.

Justeru, kajian ini dijalankan untuk mengenal pasti pengetahuan, sikap dan persepsi masyarakat terhadap kanak-kanak ASD. Antara objektif kajian ini adalah untuk; (i) mengenal pasti tahap pengetahuan, sikap, dan persepsi masyarakat tentang kanak-kanak ASD; (ii) mengenal pasti perbezaan pengetahuan, sikap dan persepsi masyarakat tentang kanak-kanak ASD berdasarkan jantina dan tahap pendidikan; dan (iii) mengenal pasti hubungan antara pengetahuan dengan sikap dan persepsi masyarakat tentang kanak-kanak ASD.

\section{METODOLOGI}

Reka bentuk kajian ini merupakan pendekatan kuantitatif yang menggunakan kaedah tinjauan. Soal selidik digunakan untuk mengumpul data berkaitan latar belakang responden, pengetahuan, sikap, dan persepsi masyarakat tentang kanak-kanak ASD. Kajian ini dijalankan di sekolah rendah yang mempunyai kelas prasekolah pendidikan khas integrasi (PPKI) di seluruh negeri Perak. Populasi kajian adalah dalam kalangan guru, ibu bapa dan penjaga murid prasekolah PPKI. Seramai 100 orang responden yang terdiri daripada guru, ibu bapa dan penjaga telah dipilih sebagai sampel kajian. Penentuan saiz sampel adalah merujuk kepada Mohd Majid (2009) yang menyatakan saiz sampel digalakkan melebihi 30 unit dengan andaian taburan normal dipenuhi apabila saiz sampel melebihi 30 unit. Mohd Majid (2009) juga menyatakan agar menggunakan sebanyak mana sampel yang boleh diperoleh kerana pertambahan saiz sampel akan lebih mewakili populasi.

Instrumen soal selidik dibina sendiri oleh pengkaji dan menggunakan Google Form untuk mengumpul data. Pengkaji mendapatkan khidmat tiga orang pakar iaitu dua orang pensyarah dan seorang guru pendidikan khas untuk menentukan kesahan konstruk dan kesahan kandungan instrumen. Soal selidik yang dibina mengandungi empat bahagian, iaitu latar belakang responden (Bahagian A), pengetahuan masyarakat tentang kanak-kanak ASD (Bahagian B), sikap masyarakat tentang kanakkanak ASD (Bahagian C), dan persepsi masyarakat tentang kanak-kanak ASD (Bahagian D). Jumlah item soal selidik adalah sebanyak 38 item, iaitu Bahagian A sebanyak enam item, Bahagian B sebanyak 12 item, Bahagian C sebanyak 11 item, dan Bahagian D sebanyak sembilan item. Soal selidik tersebut menggunakan skala Likert lima aras, iaitu sangat tidak setuju (STS), tidak setuju (TS), kurang setuju (KS), setuju (S), dan sangat setuju (SS).

Data dianalisis menggunakan Statistical Package for Sacial Science (SPSS) melalui analisis statistik deskriptif dan statistik inferensi. Analsisis deskriptif digunakan untuk menginterpretasi skor 
min bagi mengenal pasti tahap pengetahuan, sikap, dan perspesi masyarakat tentang kanak-kanak ASD. Dapatan skor min diinterpretasikan kepada tiga tahap seperti dalam Jadual 1 berikut;

Jadual 1: Penghuraian Data bagi Tahap Penilaian Skor min

\begin{tabular}{cc}
\hline Min & Tahap Penilaian \\
\hline $0.00-2.33$ & Rendah \\
$2.34-3.66$ & Sederhana \\
$3.67-5.00$ & Tinggi \\
\hline
\end{tabular}

Kajian ini juga menggunakan Ujian-t untuk mengenal pasti perbezaan tahap pengetahuan, sikap dan persepsi masyarakat tentang kanak-kanak ASD mengikut jantina. Ujian ANOVA satu hala pula digunakan untuk mengenal pasti perbezaan tahap pengetahuan, sikap dan persepsi masyarakat tentang kanak-kanak ASD mengikut tahap pendidikan. Setersunya, Korelasi Pearson digunakan untuk mengenal pasti hubungan antara tahap pengetahuan dengan sikap dan persepsi masyarakat tentang kanak-kanak ASD. Penentuaan aras kekuatan nilai pekali korelasi yang digunakan dalam kajian ini adalah berdasarkan Jadual 2 berikut;

Jadual 2: Aras Kekuatan Nilai Pekali Kolerasi (r)

\begin{tabular}{cc}
\hline Saiz Pekali Korelasi $(\mathrm{r})$ & Kekuatan Korelasi \\
\hline .91 hingga 1.00 atau -.91 hingga -1.00 & Sangat kuat \\
.71 hingga .90 atau -.71 hingga -.90 & Kuat \\
.51 hingga .70 atau -.51 hingga -.70 & Sederhana \\
.31 hingga .50 atau -.31 hingga -.50 & Lemah \\
.01 hingga .30 atau -.01 hingga -.30 & Sangat lemah \\
0.00 & Tiada kolerasi \\
\hline
\end{tabular}

(Sumber daripada Chua, 2012)

\section{DAPATAN KAJIAN}

Responden kajian ini terdiri daripada 100 orang yang terdiri daripada 82 orang perempuan (82\%) dan 18 orang lelaki $(18 \%)$. Tahap pendidikan responden terbahagi kepada beberapa peringkat, iaitu 72 orang berkelulusan Ijazah Sarjana Muda (72\%), 11 orang berkelulusan dari pelbagai peringkat yang tidak dinyatakan (11\%), lapan orang berkelulusan SPM (8\%), tujuh orang berkelulusan STPM (7\%), dan dua orang berkelulusan SRP/PMR (2\%). Berdasarkan kategori responden, 68 orang daripada guru (68\%), 22 orang daripada ibu (22\%), tujuh orang daripada bapa (7\%), dan tiga orang daripada penjaga (3\%). Perincian mengenai taburan demografi responden kajian ditunjukkan dalam Jadual 3 berikut; 
Jadual 3: Taburan Demografi Responden $(\mathrm{N}=100)$

\begin{tabular}{lcc}
\hline Item & $\mathrm{N}$ & $\%$ \\
\hline & & \\
Jantina & 82 & 82.0 \\
Perempuan & 18 & 18.0 \\
Lelaki & & \\
& & \\
Tahap Pendidikan & 2 & 2.0 \\
SRP/PMR & 8 & 8.0 \\
MCE/SPM/SPMV & 7 & 7.0 \\
STPM & 72 & 72.0 \\
Ijazah & 11 & 11.0 \\
Lain-Lain & & \\
& & \\
Kategori & 7 & 7.0 \\
Bapa & 22 & 22.0 \\
Ibu & 3 & 3.0 \\
Penjaga & 68 & 68.0 \\
Guru & & \\
Jumlah & 100 & 100 \\
\hline
\end{tabular}

\section{Tahap Pengetahuan Masyarakat tentang Kanak-kanak ASD}

Dapatan kajian menunjukkan tahap pengetahuan masyarakat tentang kanak-kanak ASD secara keseluruhan adalah tinggi, iaitu dengan skor min sebanyak 4.20 dan sisihan piawai 0.897. Skor min yang paling tinggi ialah Item 1 "Saya tahu autisme tergolong dalam anak istimewa.", iaitu sebanyak 4.75 dan sisihan piawai 0.575 . Skor min yang paling rendah pula ialah Item 5 "Saya tahu autisme boleh dikesan pada peringkat umur 12 bulan hingga tiga tahun dan saya mengesannya seawal 12 bulan.", iaitu 3.44 dan sisihan piawai 1.166. Kesemua dapatan kajian ini ditunjukkan dalam Jadual 4 berikut;

Jadual 4: Tahap Pengetahuan Masyarakat tentang Kanak-kanak AS

\begin{tabular}{|c|c|c|c|c|}
\hline & Item & Min & $\begin{array}{l}\text { Sisihan } \\
\text { Piawai }\end{array}$ & $\begin{array}{c}\text { Tahap } \\
\text { Pengetahuan }\end{array}$ \\
\hline 1. & Saya tahu autisme tergolong dalam anak istimewa. & 4.75 & 0.575 & Tinggi \\
\hline 2. & $\begin{array}{l}\text { Saya tahu tentang autisme sebelum anak saya } \\
\text { didiagnos autisme. }\end{array}$ & 3.55 & 1.274 & Sederhana \\
\hline 3. & $\begin{array}{ll}\text { Mempunyai } & \text { anak autisme } \\
\text { menjadikan } & \text { saya ibu/bapa yang istimewa. }\end{array}$ & 4.18 & 1.123 & Tinggi \\
\hline & $\begin{array}{l}\text { ya prihatin terhadap keanehan tingkah laku anak } \\
\text { le saya terutamanya ketika dia bersosial. }\end{array}$ & 4.33 & 0.842 & Tinggi \\
\hline & $\begin{array}{l}\text { a tahu autisme boleh dikesan pada peringkat umur } 12 \\
\text { hingga tiga tahun dan saya mengesannya seawal } 12\end{array}$ & 3.44 & 1.166 & Sederhana \\
\hline
\end{tabular}


6. Ada anak-anak penghidap autisme dikenal pasti memiliki Idiot savant di mana mereka mempunyai kemahiran istimewa di dalam bidang matematik atau komputer, berupaya mengingati fakta, kebolehan dalam bidang muzik dan kesenian. Anak saya mempunyai ciri tersebut.

7. Saya melihat masyarakat sekeliling sudah banyak terdedah dengan kewujudan anak-anak autisme.

8. Layanan yang mesra antara ahli keluarga menyebabkan juga boleh membantu pemulihan tingkah laku anak autisme saya.

9. Saya tahu kanak-kanak autisme ini ada tingkahlaku merosakkan dan dan kanak-kanak ini perlu dikawal dari sekarang supaya tidak berlanjutan hingga dewasa dan sukar dibendung lagi.

10. Saya merasakan anak autisme ini bukan sebagai satu masalah, tetapi mereka sebagai satu anugerah.

11. Rangsangan dan sokongan yang sesuai dengan kebolehannya akan membantu diri anak ini untuk melonjakkan kebolehannya. Jangan sesekali sekat kebolehannya kerana akan mematahkan lagi semangatnya untuk "HIDUP" dalam kelompok masyarakat.

12. Ibu bapa yang mempunyai anak istimewa mahukan anak mereka boleh berdikari dan sekurang-kurangnya ada pendapatan sendiri. Ini kerana kebanyakannya risau, apa akan terjadi kepada anak istimewa itu sekiranya mereka tiada atau meninggal dunia suatu hari

\begin{tabular}{rrrr}
\hline Min Keseluruhan & 4.20 & 0.897 & Tinggi \\
\hline
\end{tabular}

\section{Tahap Sikap Masyarakat tentang Kanak-kanak ASD}

Dapatan kajian menunjukkan tahap sikap masyarakat tentang kanak-kanak ASD secara keseluruhan adalah tinggi, iaitu dengan skor min sebanyak 3.96 dan sisihan piawai 1.059. Skor min yang paling tinggi ialah Item 3 "Memberikan anak autisme saya pendidikan khas adalah wajib.", iaitu sebanyak 4.66 dan sisihan piawai 0.572. Skor min yang paling rendah pula ialah Item 7 "Saya membiarkan anak autisme anda di rumah sahaja tanpa ikuti sebarang aktiviti terutama aktiviti terapi.", iaitu 1.89 dan sisihan piawai 1.278. Kesemua dapatan kajian ini ditunjukkan dalam Jadual 5 berikut;

Jadual 5: Tahap Sikap Masyarakat tentang Kanak-kanak ASD

\begin{tabular}{|c|c|c|c|}
\hline Item & Min & $\begin{array}{l}\text { Sisihan } \\
\text { Piawai }\end{array}$ & $\begin{array}{l}\text { Tahap } \\
\text { Sikap }\end{array}$ \\
\hline $\begin{array}{l}\text { 1. Intervensi seawal mungkin boleh membantu } \\
\text { pemulihan anak autisme saya. }\end{array}$ & 4.44 & 0.715 & Tinggi \\
\hline $\begin{array}{l}2 . \quad \text { Saya tahu autisme tidak boleh disembuhkan tetapi } \\
\text { boleh dipulihkan dengan Intervensi Awal (Early } \\
\text { Intervention). }\end{array}$ & 4.41 & 0.653 & Tinggi \\
\hline $\begin{array}{l}\text { 3. Memberikan anak autisme saya pendidikan khas } \\
\text { adalah wajib. }\end{array}$ & 4.66 & 0.572 & Tinggi \\
\hline
\end{tabular}


4. Saya tidak kisah mengeluarkan wang yang banyak untuk membantu pemulihan tingkah laku anak autisme saya.

5. Banyak cabaran yang terpaksa dilalui untuk memberikan pendidikan rasmi pada anak autisme saya.

6. Saya memberikan komitmen yang tinggi terhadap pendidikan kerohanian dan sahsiah anak-anak seawall mungkin bagi pemulihan tingkah laku anak autisme saya.

7. Saya membiarkan anak autisme anda di rumah sahaj tanpa ikuti sebarang aktiviti terutama aktiviti terapi.

8. Saya menyimpan wang simpanan untuk anak autisme saya daripada membelanjakan untuk makanan tambahan dan rawatan terapi anak autisme saya.

9. Saya tahu kewujudan kumpulan-kumpulan sokongan bagi ibubapa yang mempunyai anak-anak autisme.

10. Saya terlibat secara aktif dalam kumpulan sokongan 3.66 ibubapa yang mempunyai anak-anak autisme.

11. Saya berpendapat kasih sayang sudah cukup untuk membantu pemulihan tingkah laku anak autisme saya.
4.46
0.626
Tinggi

$4.63 \quad 0.562 \quad$ Tinggi

$4.54 \quad 0.610 \quad$ Tinggi

$1.89 \quad 1.278 \quad$ Rendah

3.42

1.415 Sederhana

4.29 $\quad 0.820 \quad$ Tinggi

$3.66 \quad 1.047 \quad$ Sederhana

$3.14 \quad 1.356 \quad$ Sederhana

3.96

1.059

Tinggi

\section{Tahap Persepsi Masyarakat tentang Kanak-kanak ASD}

Dapatan kajian menunjukkan tahap persepsi masyarakat tentang kanak-kanak ASD secara keseluruhan adalah tinggi, iaitu dengan skor min sebanyak 4.11 dan sisihan piawai 0.818 . Skor min yang paling tinggi ialah Item 8 "Guru pendidikan khas anak saya sentiasa memberi tahu perkembangan anak saya supaya tindakan sewajarnya di ambil bersama.", iaitu sebanyak 4.46 dan sisihan piawai 0.702 . Skor min yang paling rendah pula ialah Item 5 "Saya tidak kisah tentang perubahan tingkahlaku anak saya. Bagi saya selagi anak autisme saya sihat itu sudah memadai.", iaitu 2.76 dan sisihan piawai 1.288. Kesemua dapatan kajian ini ditunjukkan dalam Jadual 6 berikut;

Jadual 6: Tahap Persepsi Masyarakat tentang Kanak-kanak ASD

\begin{tabular}{ccccc}
\hline & & & Sisihan & Tahap \\
& & Mi & Piawai & Persepsi \\
\hline n 1. Intervensi & Awal (Early Intervention)telah memberi & 4.38 & 0.708 & Tinggi
\end{tabular}
kehidupan lebih baik kepada anak saya.

2. Anak autisme saya mempunyai peluang 4.09 0.922 Tinggi melanjutkan pengajian ke peringkat yang lebih tinggi.

3. Aktiviti terapi carakerja dan terapi pertuturan untuk

0.764

Tinggi sangat membantu dalam meningkatkan kemahiran anak saya serta pemulihan tingkah laku anak saya.

4. Saya melihat perubahan tingkahlaku anak saya dari semasa 4.09

$0.854 \quad$ Tinggi

ke semasa dan sentiasa merekodkannya.

5. Saya tidak kisah tentang perubahan tingkahlaku anak

Sederhana saya. Bagi saya selagi anak autisme saya sihat itu sudah memadai.

6. Saya perlu prihatin, kadang-kadang berlaku, watak 
7. Saya melihat beberapa kemahiran dan pendekatan yang

0.656

Tinggi

diajar di sekolah diteruskan dan diaplikasikan di rumah terutamanya dalam aspek pengurusan tingkah laku oleh anak autisme saya.

8. Guru pendidikan khas anak saya sentiasa memberi tahu perkembangan anak saya supaya tindakan sewajarnya di ambil bersama.

9. Sejak mendapat pendidikan dan terapi anak saya sudah mula

bersosial bersama rakan-rakannya.

$$
\text { Min Keseluruhan }
$$

4.11

0.818

Tinggi

\section{Perbezaan Pengetahuan, Sikap dan Persepsi Masyarakat tentang Kanak-kanak ASD mengikut Jantina}

Keputusan analisis Ujian-t mendapati tidak terdapat perbezaan yang signifikan iaitu $p>0.05$ antara responden lelaki dengan responden perempuan dalam aspek pengetahuan $(p=0.179)$, sikap $(p=0.827)$ dan persepsi $(p=0.321)$ tentang kanak-kanak ASD. Ini bermakna, pengetahuan, sikap dan persepsi masyarakat tentang kanak-kanak ASD adalah tidak berbeza mengikut jantina. Kesemua dapatan kajian ini ditunjukkan dalam Jadual 7 berikut;

Jadual 7: Keputusan Analisis Ujian-t berkaitan Perbezaan Tahap Pengetahuan, Sikap dan Persepsi Masyarakat tentang Kanak-kanak ASD mengikut Jantina

\begin{tabular}{lcccccc}
\hline & \multicolumn{2}{c}{ Lelaki } & \multicolumn{2}{c}{ Perempuan } \\
& Min & SP & Min & SP & Nilai t & $p$ \\
\hline Pengetahuan & 4.088 & 0.665 & 4.229 & 0.522 & -0.984 & 0.179 \\
Sikap & 3.990 & 0.480 & 3.951 & 0.464 & 0.318 & 0.827 \\
Persepsi & 4.124 & 0.649 & 4.106 & 0.478 & 0.133 & 0.321 \\
\hline
\end{tabular}

\section{Perbezaan Pengetahuan, Sikap dan Persepsi Masyarakat tentang Kanak-kanak ASD mengikut} Tahap Pendidikan

Keputusan analisis Ujian ANOVA satu hala mendapati terdapat perbezaan signifikan (nilai $p<0.05$ ) bagi pengetahuan $(\mathrm{p}=0.007)$ dan persepsi $(0.002)$ masyarakat tentang kanak-kanak ASD mengikut tahap pendidikan. Ini bermakna, pengetahuan dan persepsi masyarakat tentang kanak-kanak ASD adalah berbeza mengikut tahap pendidikan. Manakala, tidak terdapat perbezaan signifikan (nilai $p>0.05$ ) bagi sikap masyarakat $(\mathrm{p}=0.094)$ tentang kanak-kanak ASD mengikut tahap pendidikan. Ini bermakna, sikap masyarakat tentang kanak-kanak ASD adalah tidak berbeza mengikut tahap pendidikan. Kesemua dapatan kajian ini ditunjukkan dalam Jadual 8 berikut;

Jadual 8: Keputusan Analisis Ujian ANOVA Satu Hala berkaitan Perbezaan Tahap Pengetahuan, Sikap dan Persepsi Masyarakat tentang Kanak-kanak ASD mengikut Tahap Pendidikan

\begin{tabular}{llccccc}
\hline & & Jumlah & & Min kuasa & & \\
& & kuasa dua & df & dua & F & Sig. \\
\hline Pengetahuan & Antara kumpulan & 4.112 & 4 & 1.028 & & \\
& Dalam kumpulan & 25.739 & 95 & 0.271 & 3.795 & 0.007 \\
& Jumlah & 29.852 & 99 & & &
\end{tabular}




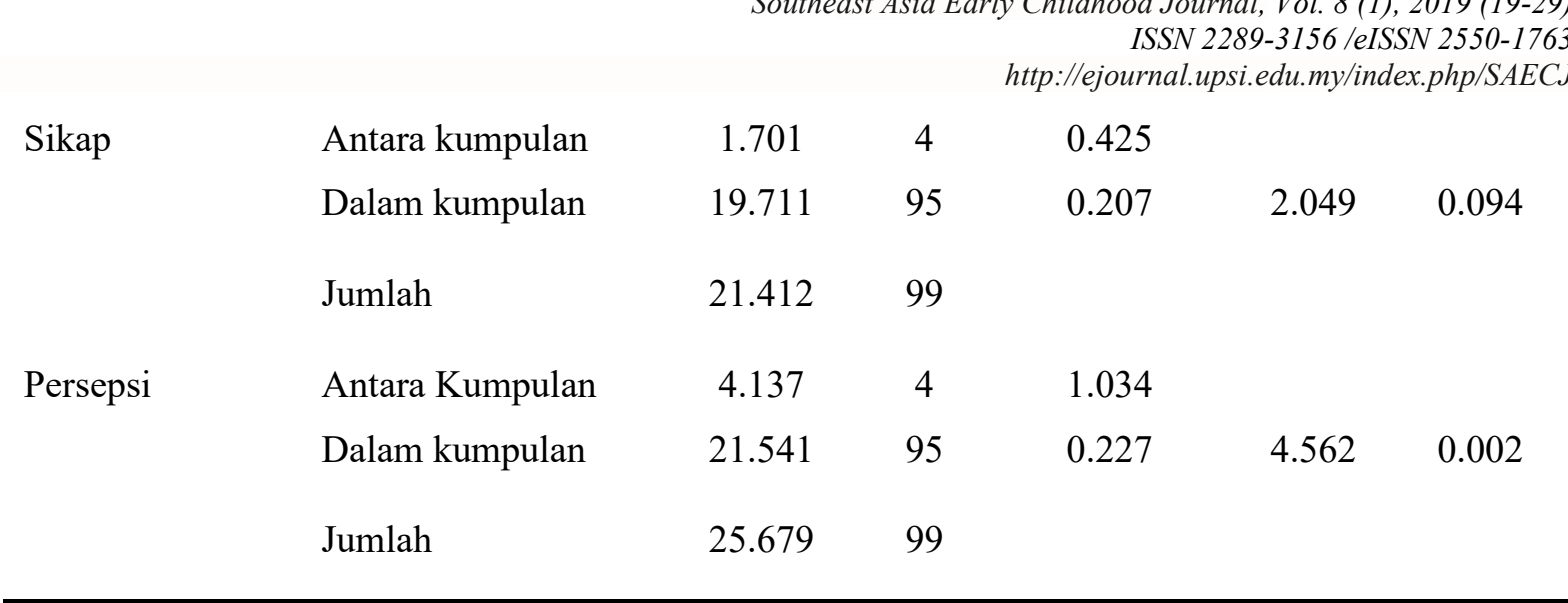

\section{Hubungan antara Pengetahuan dengan Sikap Masyarakat tentang Kanak-kanak ASD}

Keputusan analisis korelasi menunjukkan terdapat hubungan signifikan antara pengetahuan dengan sikap masyarakat tentang kanak-kanak ASD dengan nilai $\mathrm{p}=0.000$. Nilai $p$ adalah kurang daripada aras keertian $\alpha(p<0.01)$, maka terdapat hubungan signifikan antara pengetahuan dengan sikap masyarakat tentang kanak-kanak ASD. Nilai kolerasi $r=0.617$ menunjukkan terdapat hubungan kolerasi positif yang sederhana antara pengetahuan dengan sikap masyarakat tentang kanak-kanak ASD. Dapatan kajian ini ditunjukkan dalam Jadual 9 berikut;

Jadual 9: Analisis Korelasi antara Pengetahuan dengan Sikap Masyarakat tentang Kanak-kanak ASD

\begin{tabular}{lcccc}
\hline & \multicolumn{2}{c}{ Pengetahuan } & \multicolumn{2}{c}{ Sikap } \\
& $p$ & $r$ & $p$ & $r$ \\
\hline $\begin{array}{l}\text { Pengetahuan } \\
\text { Sikap }\end{array}$ & 0.000 & $0.617^{* *}$ & 0.000 & $0.617^{* *}$ \\
\hline$p<0.01^{* *}$ & & & \\
\hline
\end{tabular}

\section{Hubungan Antara Pengetahuan dengan Persepsi Masyarakat tentang Kanak-kanak ASD}

Keputusan analisis korelasi menunjukkan terdapat hubungan signifikan antara pengetahuan dengan persepsi masyarakat tentang kanak-kanak ASD dengan nilai $\mathrm{p}=0.000$. Nilai $p$ adalah kurang daripada aras keertian $\alpha(p<0.01)$, maka terdapat hubungan signifikan antara pengetahuan dengan persepsi masyarakat tentang kanak-kanak ASD. Nilai kolerasi $r=0.728$ menunjukkan terdapat hubungan kolerasi positif yang sederhana antara pengetahuan dengan persepsi masyarakat tentang kanak-kanak ASD. Dapatan kajian ini ditunjukkan dalam Jadual 10 berikut;

Jadual 10: Analisis Korelasi antara Pengetahuan dengan Persepsi Masyarakat tentang Kanak-kanak ASD

\begin{tabular}{lcccc}
\hline & \multicolumn{2}{c}{ Pengetahuan } & \multicolumn{2}{c}{ Persepsi } \\
& $p$ & $r$ & $p$ & $r$ \\
\hline $\begin{array}{l}\text { Pengetahuan } \\
\text { Persepsi }\end{array}$ & 0.000 & $0.728^{* *}$ & 0.000 & $0.728^{* *}$ \\
\hline$p<0.01^{* *}$ & & & \\
\hline
\end{tabular}




\section{PERBINCANGAN DAN IMPLIKASI KAJIAN}

Walaupun tahap pengetahuan, sikap dan persepsi masyarakat tentang kanak-kanak ASD adalah tinggi, namun begitu tidak semua benar-benar memahami dan mengetahui tentang ASD. Hal ini kerana masyarakat hanya pernah mendengar mengenai ASD tetapi tidak memahami ciriciri kanak-kanak ASD. Kajian ini juga mendapati tidak terdapat perbezaan yang signifikan antara responden lelaki dengan responden perempuan dalam aspek pengetahuan, sikap dan persepsi masyarakat tentang kanak-kanak ASD. Ini menunjukkan jantina tidak mempengaruhi pengetahuan, sikap dan persepsi masyarakat tentang kanak-kanak ASD.

Selain itu, kajian ini mendapati pengetahuan dan persepsi masyarakat tentang kanakkanak ASD adalah berbeza mengikut tahap pendidikan. Dapatan kajian juga menunjukkan terdapat hubungan kolerasi positif yang sederhana antara pengetahuan dengan sikap dan persepsi masyarakat tentang kanak-kanak ASD Oleh itu, kesedaran masyarakat perlu ditingkatkan dengan adanya pelbagai pendedahan daripada media sosial dan cakna dalam pendidikan di sekolah berkaitan ASD. Dengan adanya sokongan daripada semua pihak, maka kesedaran dalam masyarakat akan meningkat (Quirantes, 2009).

Implikasi kajian ini dalam aspek teori adalah dapat meneroka penyelidikan berkaitan penerimaan masyarakat terhadap kanak-kanak ASD di Malaysia. Kajian ini mampu memberi maklumat dan gambaran sejauhmana tahap pengetahuan, sikap dan persepsi masyarakat terhadap kanak-kanak ASD. Ini setersunya yang menyumbang kepada penerimaan masyarakat terhadap kanak-kanak ASD.

Implikasi kajian ini dalam aspek amali pula ialah masyarakat perlu lebih banyak membaca dan mendapatkan maklumat berkaitan simptom-simptom ASD dalam usaha untuk meningkatkan kefahaman mereka mengenai kriteria utama bagi anak-anak yang mengalami masalah ASD secara lebih mendalam. Maka itu, peranan media sosial diperlukan dalam membina cakna dalam kalangan masyarakat di Malaysia.

Walau bagaimanapun, dapatan kajian ini tidak dapat digeneralisasikan sepenuhnya kerana melibatkan sampel yang tidak seimbang dalam aspek jantina dan kategori responden. Pengkaji mencadangkan agar kajian lanjutan dijalankan dengan melibatkan responden dan lokasi kajian yang lebih meluas dan lebih seimbang. Kajian lanjutan juga boleh dilaksanakan bagi mengenal pasti tahap kesedaran masyarakat terhadap perkara utama yang diperlukan oleh kanak-kanak ASD dalam usaha untuk membantu mereka mendapat pendidikan yangterbaik. Selain itu, kajian yang lebih mendalam boleh dijalankan bagi meneroka secara kualitatif berkaitan pengaruh yang mempengaruhi tahap pengetahuan, sikap dan persepsi masyarakat terhadap kanak-kanak ASD.

\section{KESIMPULAN}

Penerimaan masyarakat terhadap kanak-kanak ASD merupakan satu perkara yang amat penting bagi mewujudkan keselesaan kepada kanak-kanak ASD itu sendiri. Bagi masyarakat yang tidak memahami kriteria sebenar kanak-kanak ASD, ianya boleh membawa tanggapan yang negatif terhadap kanakkanak ASD. Oleh itu, masyarakat perlu memainkan peranan masing-masing dalam memastikan kanakkanak ASD mendapat rawatan dan penjagaan khusus, dan menggalakkan perkembangan kanak-kanak ASD mengikut kaedah dan pendekatan yang betul. 


\section{RUJUKAN}

Chua, Y. P. (2012). Asas statistik penyelidikan (Kedua). Kuala Lumpur: Mc Graw Hill (Malaysia) Sdn. Bhd.

Hasnah Toran, Mohd. Hanafi Mohd. Yasin, Mohd. Mokhtar Tahar, \& Norani Salleh. (2010). Tahap latihan, pengetahuan dan keyakinan guru-guru pendidikan khas tentang autisme. Jurnal Pendidikan Malaysia, $35(1), 19-25$.

Khairul Azhar Idris. (2018). Kesedaran autisme dalam masyarakat. Utusan Online

Majin, M., Hashmi, S. I., \& Sombuling, A. (2017). Kesedaran guru di Kota Kinabalu, Sabah dalam pengetahuan dan persepsi terhadap Autism Spectrum Disorder (ASD). Jurnal Psikologi Malaysia, 31(3), 56-63.

Meiriawan Sulistyo, Abdul Salim Choiri, \& Furqan Hidayatulloh. (2017). Decreasing tantrum of child with Autism using Brain Gym. European Journal of Special Education Research, 2(2).

Mohd Majid, K. (2009). Kaedah penyelidikan pendidikan (Keenam). Ampang: Dawana Sdn. Bhd.

Mohd Najib, A. G. (2006). Reka bentuk tinjauan soal selidik pendidikan. Skudai, Johor: Universiti Teknologi Malaysia.

Mohd Suhaimi Mohamad \& Nur Natasha Amelia Rosdi. (2018). Hubungan antara tingkah laku keibubapaan, tekanan psikologikal dengan tahap kesihatan mental dalam kalangan penjaga kanak-kanak autisme. Jurnal Psikologi Malaysia, 32(4). 123-132.

Quirantes, D. (2009). Collaborative approach to autism: A parent's perspective. Journal for Specialist in Pediatric Nursing, 14(3), 203-205.

Siti Marziah Zakaria \& Nor Shahirah Mat Tauhaid. (2018). Cabaran membesarkan anak-anak autisme daripada perspektif ibu. Jurnal Psikologi Malaysia, 32(1), 58-71.

Soltanifar, A., Akbarzadeh, F., Moharreri, F., Soltanifar, A., Ebrahimi, A. Mokhber, N., \& Naqvi, S. S. A. (2015). Comparison of parental stress among mothers and fathers of children with Autistic Spectrum Disorder in Iran. Iranian Journal of Nursing and Midwifery Research, 20, 93-98

Suhaily Md Shamsudin \& Siti Syuhada Abd Rahman. (2017). Public awareness on the characteristics of children with autism in Selangor. Malaysian Online Journal of Education, 1(2), 73-81. 